ELORE (ISSN 1456-3010), vol. 19 - 2/2012.

Julkaisija: Suomen Kansantietouden Tutkijain Seura ry.

[http://www.elore.fi/arkisto/2_12/leppalahti_arvio.pdf]

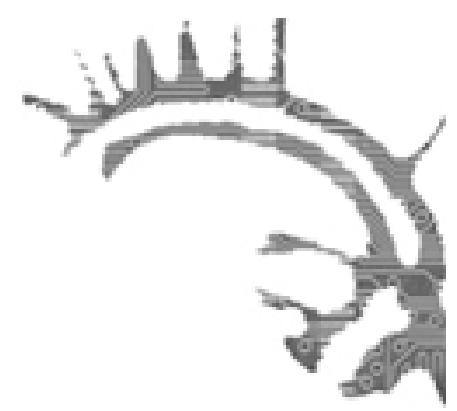

\title{
KIRJA-ARVIO
}

\section{PYHIÄ JA ARKISIA ESINEITÄ}

NIEMINEN, AILA \& OLSSON, PIA \& RUOTSALA, HELENA \& SIIVONEN KATRIINA (toim.) 2011: Aineen taikaa. Näkyvän ja näkymättömän kulttuurin jäljillä. Helsinki: SKS. 365 sivua.

\section{Merja Leppälahti}

Teppo Korhosen juhlakirjaksi toimitettu Aineen taikaa sisältää johdannon lisäksi seitsemäntoista artikkelia. Nämä on jaettu kolmeen osioon, "Ylevöittävä aine", "Kosmos arjessa" ja "Taivaltavat juuret". Kirjoittajina on kansatieteilijöiden ja etnologien lisäksi arkeologian, folkloristiikan, sosiaali- ja kulttuuriantropologian sekä taidehistorian dosentteja ja professoreja, tunnettuja ja arvostettuja tieteenharjoittajia.

Kirjan kannen on suunnitellut Jaana Tarsa. Ulkoasultaan Aineen taikaa on poikkeuksellisen onnistunut ja suorastaan houkutteleva. Kannessa oleva puinen ovi tai laatikon kansi on valmiina avautumaan päästääkseen lukijan tutustumaan kirjan sisältöön. Myös kannen materiaali sopii kansikuvaan.

\section{YLEVÖITTÄVÄ AINE}

Useimmat kirjan artikkeleista käsittelevät selkeästi menneisyyttä, vaikka monista vedetään linjoja myös nykyaikaan. Poikkeuksen tekee Pia Olssonin artikkeli "Leijumista ja esineherkuttelua?", jonka aineisto on kerätty vuonna 2010. Olsson on haastatellut 
Merja Leppälahti: Pyhiä ja arkisia esineitä

yläasteikäisiä poikia kysellen heiltä muun muassa vaatteiden ja tavaroiden merkityksestä kaverisuhteissa. Vaatteisiin, asusteisiin ja niiden merkityksiin liittyvät muutkin "Ylevöittävä aine"-osion tekstit, Anna Maria Viljasen "Romaninaisen puku", Juhani U. E. Lehtosen "Naisten sotilaspuvut" ja myös Satu Apon "Tuhkimon kenkä”.

Sekä romaninaisen että naissotilaan puku kertoo käyttäjänsä statuksesta. Romanipuvun päälleen pukeva nainen ilmoittaa puvullaan sitoutuneensa romanien käyttäytymissääntöihin. Valtaväestön edustaja voi kuvitella romanipukua ikivanhaksi, mutta todellisuudessa puku on muuttunut ajan myötä. Esimerkiksi nykyään katukuvassa näkyvät romaninaisten samettihameet ovat tulleet käyttöön vasta 1920-luvulla. Se taas ei liene yllättävää, että naisten sotilaspuvut ovat jäljitelleet miesten vastaavia asuja. Tosin naisten puvuissa on yleensä hameen lisäksi ollut selviä eroja miesten pukuihin verrattuna. Käytännön tilanteessa, kuten ase kädessä taistelleiden punakaartilaisnaisten kohdalla, housut ja lyhyet hiukset korostivat Lehtosen mukaan paitsi käytännöllisyyttä myös vallankumouksellista epäsovinnaisuutta. Tuhkimon kenkä puolestaan on taikaesine, joka paljastaa oikean neidon, sillä kenkä sopii vain yhdelle ainoalle tytölle.

\section{Kosmos ARJESSA}

Taikaesineitä käsittelee myös toisen osion ensimmäinen artikkeli, Ulla Pielan "Esineen taikaa”. Tietäjän käytössä näennäisen mitättömät esineet siirsivät maagisia merkityksiä tästä maailmasta tuonpuoleiseen ja toisin päin. Myös seuraava artikkeli, Jussi-Pekka Taavitsaisen ja Markus Hiekkasen "Pyhän Gertrudin pyhäinjäännös Turun tuomiokirkossa", kertoo esineistä, joilla on maagista voimaa. Artikkeli valottaa kiinnostavasti myös pyhäinjäännösten olemusta ja niiden tutkimusta. Muut toisen osion artikkeleista ovat Ildikó Lehtisen "Lahja jumalille", Katriina Siivosen "Maton muisti", Bo Lönnqvistin "Nukkekaapin arvoitus", Leena Sammallahden "Lilly von Heidemanin kaappi" ja Outi Tuomi-Nikulan "Pelon kulttuuriperintö". Viimeksi mainittu käsittelee noin kerran sukupolvessa tapahtuviin myrskytulviin liittyvää aineellista ja aineetonta kulttuuriperintöä Altes Landin alueella Pohjois-Saksassa.

Lehtisen, Siivosen ja Sammallahden artikkelit käsittelevät jokaisesta kodista löytyviä tavallisia käyttöesineitä, pyyhkeitä, mattoa ja kaappia, jotka kuitenkin ovat näissä artikkeleissa erityisiä ja merkityksellisiä. Lehtinen tarkastelee artikkelissaan pyyheliinan moninaisia käyttöyhteyksiä ja merkityksiä marilaisessa Untšon kylässä. Siivosen artikkelissa vanhan mallin mukaisen uuden maton kutominen on herättänyt kysymyksen riepumaton kantamista muistoista, Sammallahti taas jäljittää artikkelissaan vanhan kaapin tuntematonta tekijää. Lönnqvistin nukkekaappi-artikkelissa tarkastelun kohteena ei ole varsinainen käyttöesine. Nukkekaappi näyttäytyy tosimaailman miniatyrisointina, viehättävän täydellisenä ja ihanteellisena mikrokosmoksena, joka oli tarkoitettu katseltavaksi, ei leikittäväksi. Lapsiin ja leikkikalumaailmaan nukkekaappi on Lönnqvistin mukaan liitetty vasta myöhemmin. 
Merja Leppälahti: Pyhiä ja arkisia esineitä

\section{TAIVALTAVAT JUURET}

Kolmas osio on nimeltään "Taivaltavat juuret" ja se sisältää kuusi artikkelia. Hanna Snellman tarkastelee artikkelissaan "Muistoja Suomesta" suomalais-ruotsalaisena yhteistyönä toteutettua Ruotsissa asuvien suomalaissiirtolaisten dokumentointihanketta ja pohtii myös 1970-luvun aineiston käyttökelpoisuutta nykypäivän tutkijoille. Helena Ruotsalan artikkeli "Suopunki viinekkeille ja kuksa reppuun" valottaa porotalouteen liittyvien esineiden asemaa poronhoidon modernistuessa ja teknistyessä. Kuksa on hyvä esimerkki käyttöesineestä, joka tunnetaan laajalti myös matkamuistoesineenä. Toisaalta joidenkin perinteisten käsityönä tehtyjen esineiden koneellinen valmistaminen turismia varten on herättänyt keskustelua.

Anna-Maria Åströmin artikkeli "Kartanoiden pihat ja eräät talousrakennukset" ja Ulla Vuorelan artikkeli "Mitä kuistin takana?" käsittelevät rakennusperinnettä. Åströmin artikkelissa paljastuu hauskasti, miten esimerkiksi vilja-aittojen sijoittelussa voi näkyä myös talon arvovallan korostaminen. Vuorelan artikkeli taas on eräänlainen jatkopuheenvuoro Teppo Korhosen Kuisti-kirjalle, joka ilmestyi vuonna 1991. Tuula ja Pekka Leimun artikkelissa "Erään kaluston tarina" tarkastellaan Alfred Kordelinille Naantalin Kultarantaan suunnitellun ja teetetyn ruokasalin kaluston vaiheita Turun yliopiston kautta Liedon Vanhalinnan museoon. Kokoelman päättää Seppo Knuuttilan artikkeli "Etnografiset käänteet perinnetieteiden yhdistäjinä?"

\section{LOPUKSI}

Kirjan lopussa on asiaankuuluvasti tiedot kirjoittajista, mutta minkäänlaisia henkilö- tai asiahakemistoja ei valitettavasti ole. Koska Aineen taikaa on toimitettu Teppo Korhosen juhlakirjaksi, kirjan lopussa on myös luettelo Korhosen julkaisuista, mikä on laajuudessaan sekä kunnioitusta että mielenkiintoa herättävä.

Alaotsikkonsa Näkyvän ja näkymättömän kulttuurin jäljillä mukaisesti Aineen taikaa yhdistää aineellista ja aineetonta perinnettä ja kulttuuria. Artikkelit itsessään ovat varsin erilaisia ja niiden kokoaminen kolmen yhteisen pääotsikon alle on paikoin hiukan väkinäistä, näinhän juhlakirjojen artikkeleiden kohdalla tapaa usein olla. Toisaalta juuri artikkelien laajakirjoisuus tekee kirjasta mielenkiintoisen ja monipuolisen katsauksen esineisiin liittyvän perinteen laajaan kenttään. Teosta voikin hyvin suositella lukemistoksi kulttuurintutkimuksen moninaisuudesta kiinnostuneille.

\section{KirjallisuUs}

KORHONEN, TEPPO 1991: Kuisti: kansatieteellinen tutkimus. Helsinki: Suomen muinaismuistoyhdistys.

Filosofian lisensiaatti Merja Leppälahti on turkulainen tietokirjailija ja kriitikko. 